\title{
Overexpression of the Ets-I transcription factor in human breast
}

\section{cancer}

\author{
Y Buggy',2, TM Maguire', G McGreal', E McDermott', ADK Hill ',2, N O'Higgins' and MJ Duffy", , 2,3 \\ 'Department of Surgery, University College Dublin, St Vincent's University Hospital, Dublin 4, Ireland; ${ }^{2}$ Conway Institute of Biomolecular and Biomedical \\ Research, University College Dublin, Dublin 4, Ireland; ${ }^{3}$ Department of Nuclear Medicine, St Vincent's University Hospital, Dublin 4, Ireland
}

The Ets family of transcription factors regulate expression of multiple genes involved in tumour progression. The aim of this study was to investigate the expression of Ets- I in a large panel of human breast cancers and relate its levels to the parameters of tumour progression and metastasis. Using RT-PCR, Ets-I mRNA was detected in 30 out of 42 (7I\%) fibroadenomas and I 3 I out of I79 (73\%) primary breast carcinomas. Similarly, levels of Ets-I mRNA were not significantly different in fibroadenomas and primary breast carcinomas. Using Western blotting, four forms of the Ets- I protein were detected, that is, p33, p42, p5 I and p52. Levels of both p5 I and $p 52$ but not $p 33$ and $p 42$ were present at significantly higher levels in the carcinomas compared to the fibroadenomas (for p5 I, $P<0.007$; for $p 52, P<0.02$; Mann-Whitney $U$-test). Levels of p52, p5I and p33 correlated significantly with uPA protein levels $(P<0.0$ I $)$, while only levels of p52 correlated significantly with HER-2/neu protein levels $(P<0.0$ I $)$. Using immunohistochemistry, EtsI was found predominantly in tumour cells, but was also detected in some stromal cells surrounding tumour islands. We conclude that, while at the mRNA level, Ets- I was found at similar levels in fibroadenomas and primary breast carcinomas, higher protein levels were detected in the cancers compared to the benign specimens. Since p52, p5I and p33 correlate with uPA levels, these forms of Ets-I may play a role in breast cancer metastasis.

British Journal of Cancer (2004) 91, I308-1315. doi:10.1038/sj.bjc.6602128 www.bjcancer.com

Published online 7 September 2004

(c) 2004 Cancer Research UK

Keywords: Ets transcription factors; HER-2/neu; urokinase plasminogen activator (UPA); invasion; breast cancer

E26 transformation-specific (Ets) genes encode a family of transcription factors, which have been shown to regulate a diverse array of biological functions (Wasylyk et al, 1993). The criterion for membership of this family is an approximate 85-amino-acid consensus motif known as the Ets domain (Papas et al, 1989; Janknecht and Nordheim, 1993; Wasylyk et al, 1993; Mavrothalassitis et al, 1994; Tymms and Kola, 1994). The Ets motif is necessary for the specific recognition of a purine-rich core sequence, GGAA/T, within the promoter/enhancer regions of multiple target genes (Higashino et al, 1995; Himelstein et al, 1997). This domain appears to possess a unique structural motif for binding DNA with high specificity (Wasylyk et al, 1993). Amongst the genes whose promoter/enhancer regions contain Etsbinding sites (EBSs) are several matrix-degrading proteases such as the urokinase plasminogen activator ( $\mathrm{uPA}$ ), cathespin $\mathrm{B}$, matrix metalloproteinase (MMP)-1, MMP-3 and MMP-9 (White et al, 1997; Kitange et al, 1999; Sementchenko and Watson, 2000; Behrens et al, 2001) and genes coding for adhesion proteins such as specific integrins, cadherins and selectins (Sementchenko and Watson, 2000).

Ets-1, the founder member of the Ets gene family, is located on the long arm of chromosome 11 (11q23-q24). Ets-1 is the cellular homologue of the $v$-Ets gene found in the avian erythroblastosis virus E26 (Watson et al, 1990). In humans, the Ets-1 gene encodes

*Correspondence: Dr MJ Duffy; E-mail: michael.j.duffy@ucd.ie Received 31 March 2004; revised 5 July 2004; accepted 16 July 2004; published online 7 September 2004 two mRNA transcripts, a full-length $(6.8 \mathrm{~kb})$ transcript and an alternatively spliced (2.7 kb) transcript (Koizumi et al, 1990; Collyn d'Hooghe et al, 1993). The full-length transcript encodes both a $51 \mathrm{kDa}$ protein and a $42 \mathrm{kDa}$ protein (Bhat et al, 1996). The $51 \mathrm{kDa}$ protein can be phosphorylated as a result of increased intracellular calcium levels, giving rise to a $52 \mathrm{kDa}$ protein (Bhat et al, 1996). The $42 \mathrm{kDa}$ protein lacks exon VII, which contains the major phosphorylation site in the full-length protein (Jorcyk et al, 1991).

Ets proteins are targets for phosphorylation in response to stimulation by a variety of different growth modulators, including intracellular calcium, activators of protein kinase C pathways, growth factors and cytokines (Bhat et al, 1996). Variations in the degree of activation of the Ets-1 protein seen in different cell types may arise from differential phosphorylation or dephosphorylation within a given cell (Pognonec et al, 1990).

In model systems, increased expression of Ets-1 was found to be associated with enhanced angiogenesis and the invasive phenotype (Vandenbunder et al, 1994a, b; Ito et al, 1998; Sato et al, 2000). In addition, several angiogenic factors, such as the vascular endothelial growth factor (VEGF) and both acidic and basic fibroblast growth factor (FGF), have been shown to induce expression of Ets-1 (Wernert et al, 1994; Sato et al, 2000). In a preliminary report, Span et al (2002) recently showed that high expression of Ets-1 was associated with adverse prognosis in breast cancer. In that study, the authors also found a significant correlation between Ets-1 levels and both VEGF and plasminogen activator inhibitor-1 (PAI-1) (Span et al, 2002). All these findings, taken together, suggest that Ets-1 is likely to play a key role in cancer progression, especially angiogenesis and invasion. 
In this study, we investigated the ex vivo expression of Ets-1 in a panel of human breast tissues using reverse transcriptasepolymerase chain reaction (RT-PCR), Western blotting and immunohistochemistry. We also related levels of Ets-1 to the established prognostic factors for breast cancer and factors involved in tumour progression, that is, urokinase plasminogen activator (uPA) and human epidermal growth factor receptor 2 (HER-2/neu).

\section{MATERIALS AND METHODS}

\section{Human breast tissues}

Breast tissue specimens were obtained during surgery, and, following histopathological examination, the remainder of each sample was immediately frozen in liquid nitrogen. The samples were then powdered using the Braun Mikrodismembrator (Braun Apparate, Melsungen, Germany) and the powder stored at $-80^{\circ} \mathrm{C}$ until further use. The characteristics of the breast cancers used in this study are summarised in Table 1 . In total, 179 primary breast carcinomas were analysed for Ets-1 mRNA expression and of these 78 were randomly selected for analysis of Ets-1 protein expression. In all, 42 fibroadenomas were analysed for Ets-1 mRNA expression, 38 of which were tested for Ets-1 protein expression. Immunohistochemistry was carried out on cryosections from seven primary breast carcinomas and seven fibroadenomas. The quality of each section and the relative cellular composition were determined by histopathological assessment. Ethical approval for this study was issued by the Ethics Committee, St Vincent's University Hospital, Dublin, Ireland.

\section{RNA extraction}

Total RNA was extracted from 100-200 mg of breast tissue using the guanidine isothiocyanate/phenol chloroform method (Chomc-

Table I Characteristics of breast cancers used

\begin{tabular}{|c|c|c|}
\hline Variable & $n$ & $\%$ positive \\
\hline \multicolumn{3}{|l|}{ Nodal status } \\
\hline Negative & 80 & 44.6 \\
\hline Positive & 89 & 49.7 \\
\hline Unknown & 10 & 5.7 \\
\hline \multicolumn{3}{|l|}{ Tumour size } \\
\hline $\mathrm{TI}(\leqslant 2 \mathrm{~cm})$ & 45 & 25 \\
\hline $\mathrm{T} 2(2-5 \mathrm{~cm})$ & 91 & 51 \\
\hline $\mathrm{T} 3-4(\geqslant 5 \mathrm{~cm})$ & 29 & 16 \\
\hline Unknown & 14 & 8 \\
\hline \multicolumn{3}{|l|}{ Histology type } \\
\hline Ductal (D) & 133 & 74.3 \\
\hline Lobular (L) & 27 & 15 \\
\hline$D \& L$ & 10 & 5.7 \\
\hline Unknown & 9 & 5 \\
\hline \multicolumn{3}{|l|}{ ER status ${ }^{\mathrm{a}}$} \\
\hline Negative & 50 & 28 \\
\hline Positive & 128 & 71.5 \\
\hline Unknown & 1 & 0.5 \\
\hline \multicolumn{3}{|l|}{ PR status ${ }^{b}$} \\
\hline Negative & 73 & 41 \\
\hline Positive & 77 & 43 \\
\hline Unknown & 29 & 16 \\
\hline
\end{tabular}

$E R=$ oestrogen receptor. $P R=$ progesterone receptor. ${ }^{a}$ Cutoff point $=200 \mathrm{fmol} \mathrm{g}^{-1}$ of wet weight tissue. ${ }^{b}$ Cutoff point $=1000 \mathrm{fmolg}^{-1}$ of wet weight tissue. zynski and Sacchi, 1987). The integrity of the RNA was visualised by running $10 \mu \mathrm{l}$ on a $2.5 \%$ agarose gel with ethidium bromide staining and checking the integrity of the $28 \mathrm{~S}$ and $18 \mathrm{~S}$ bands. The purity of RNA was determined by reading the absorbance at $260 \mathrm{~nm}$.

\section{Complementary strand DNA (cDNA) synthesis}

Total RNA $(1 \mu \mathrm{g})$ was reversed transcribed to single-stranded cDNA in a final volume of $20 \mu$ l. The reaction mixture contained $0.4 \mathrm{~mm}$ of each deoxynucleotide triphosphates (dNTP), $10 \mu \mathrm{g} \mathrm{ml}^{-1}$ of Oligo (dT) $)_{12-18}, 10 \mathrm{~mm}$ dithiolthreitol (DTT), $50 \mathrm{~mm}$ Tris $-\mathrm{HCl}$ ( $\mathrm{pH} 8.3$ ), $75 \mathrm{~mm} \mathrm{KCL}$ and $3 \mathrm{~mm} \mathrm{MgCl}_{2}$. This reaction mixture was incubated for $5 \mathrm{~min}$ at $70^{\circ} \mathrm{C}$ to remove secondary RNA structures, centrifuged and cooled on ice, followed by the addition of $4.6 \mathrm{U}$ of human placenta ribonuclease inhibitor $\left(\mathrm{GibcoBRL}^{\mathbb{R}}\right)$ and $200 \mathrm{U}$ of Moloney murine leukaemia virus reverse transcriptase (Promega). Samples were incubated for $1 \mathrm{~h}$ at $37^{\circ} \mathrm{C}$ and finally heated for $5 \mathrm{~min}$ at $65^{\circ} \mathrm{C}$. cDNA was stored aliquoted at $-20^{\circ} \mathrm{C}$ until required for PCR amplification.

\section{PCR}

Semiquantitation of Ets-1 and uPA was performed following co-amplification and normalisation with an internal control sequence, glyceraldehydes-3-phosphate-dehydrogenase (GAPDH). The primers for Ets-1 and GAPDH were designed and numbered according to Genbank notation (Accession numbers $=\mathrm{NM}_{-}$ 005238, NM_002046). Primers specific for the amplification of the transcripts were chosen using the 'Primer Select' software, and the specificity confirmed by carrying out a detailed BLAST search. Details of all primer pairs are as follows:

Ets-1: sense, 5'-CGC TAT ACC TCG GAT TAC TT-3'; antisense, 5'-GTC ATA GGA GGG AAC ACG-3' (nucleotides 735-754 and $1113-1130$, respectively).

GAPDH: sense, $5^{\prime}$-CCA CCC ATG GCA AAA TTC CAT GGC A3'; antisense, 5'-TCT AGA CGG CAG GTC AGG TCC ACC-3' (nucleotides 227-250 and 801-824, respectively; Crofford et al, 1993).

The PCR reaction comprised of $2 \mu \mathrm{l}$ of cDNA template obtained from $1 \mu \mathrm{g}$ of RNA, $100 \mathrm{ng}$ each of upstream and downstream primers (Genosys, Pampisford, UK), $0.25 \mathrm{~mm}$ each of dNTP, $2.0 \mathrm{mM} \mathrm{MgCl}_{2}$ and $1.25 \mathrm{U}$ of Taq DNA polymerase (Promega) in a reaction buffer made up to a final volume of $50 \mu$ l. All PCR reactions were performed in an automated thermocycler (MJ Research, Watertown, MA, USA). The cycling conditions for each of the primer sets were as follows:

Ets-1: A denaturing step for $2 \mathrm{~min}$ at $94^{\circ} \mathrm{C}$, followed by $1 \mathrm{~min}$ at $94^{\circ} \mathrm{C}, 1 \mathrm{~min}$ at $58^{\circ} \mathrm{C}$ and $1 \mathrm{~min}$ at $72^{\circ} \mathrm{C}$ for 33 cycles, followed by $5 \mathrm{~min}$ at $72^{\circ} \mathrm{C}$.

GAPDH: A denaturing step for $2 \mathrm{~min}$ at $94^{\circ} \mathrm{C}$, followed by $1 \mathrm{~min}$ at $94^{\circ} \mathrm{C}, 1 \mathrm{~min}$ at $60^{\circ} \mathrm{C}$ and $1 \mathrm{~min}$ at $72^{\circ} \mathrm{C}$ for $30 \mathrm{cycles}$, followed by $5 \mathrm{~min}$ at $72^{\circ} \mathrm{C}$

With these conditions, amplification products were obtained in the exponential phase for both sets of primers used. Following amplification, $20 \mu \mathrm{l}$ of PCR product from each reaction was run out on a $2.5 \%$ agarose gel and visualised by ethidium bromide staining under UV light. The intensity of the bands was determined by densitometry (EagleEye ${ }^{\mathrm{TM}}$, Stratagene, UK), and expressed as a ratio of the GAPDH band intensity, which was used as an internal control. Negative controls included omission of reverse transcriptase and replacement of cDNA by water. The identity of the PCR products was confirmed by direct sequencing (ABI prism 310 technology). For all reactions, the product agreed with the expected sequence $\geqslant 98 \%$. 


\section{Western blot analysis}

Frozen powdered tissue samples were suspended in $50 \mathrm{~mm}$ Tris $\mathrm{HCl}$ (pH 7.4) (2 ml per $100 \mathrm{mg}$ of sample) containing Triton X-100 to a final concentration of $1 \%\left(\mathrm{vv}^{-1}\right)$. These homogenates were agitated for $20 \mathrm{~min}$ at $4{ }^{\circ} \mathrm{C}$ and centrifuged at $13000 \mathrm{~g}$ for $20 \mathrm{~min}$ at $4^{\circ} \mathrm{C}$. The pellet was discarded and the supernatant containing the protein was transferred to a clean tube. Total protein concentration was determined using the micro-bicinchoninic acid (BCA) protein assay (Pierce, Rochford, IL, USA) according to the manufacturer's instructions. Samples each containing $30 \mu \mathrm{g}$ of protein, along with molecular weight marker (SeeBlue TM Prestained standards, Novex, USA) and a positive control for the antibody (Jurkat cell lysate, Upstate Biotechnology, Lake Placid, NY, USA), were subjected to $12 \%$ polyacrylamide gel electrophoresis under reducing conditions, and the proteins were transferred to a nitrocellulose membrane (Sigma Chemical Company, St Louis, MO, USA).

After nonspecific sites were blocked with $5 \%$ powdered milk in $0.05 \%$ Triton X-100/Tris-buffered saline (TBS-T) for $1 \mathrm{~h}$, blots were incubated overnight with an IgG-purified rabbit polyclonal Ets-1 (C-20) antibody at a final concentration of $0.4 \mu \mathrm{g} \mathrm{ml}^{-1}$ (Santa Cruz Biotechnology, Inc) in a solution containing $5 \%$ powdered milk and $0.05 \%$ Triton X-100/TBS. The blots were then washed three times in TBS-T for $10 \mathrm{~min}$ each and incubated with a HRPconjugated goat anti-rabbit IgG (Sigma-Aldrich Ireland Ltd, Dublin, Ireland) at a concentration of $1 \mu \mathrm{g} \mathrm{ml}^{-1}$ in $5 \%$ powdered milk in $0.05 \%$ TBS-T. All samples were also blotted for $\beta$-actin (Clone AC-15, Sigma-Aldrich, Ireland Ltd, Dublin, Ireland) to normalise protein amounts. Bands were detected by the addition of a chemiluminescent substrate (Luminol system, Santa Cruz Biotechnology, Inc). Blots were exposed to Fuji X-ray film for $3 \mathrm{~min}$. Scanning densitometry was performed on the protein bands using the EagleEye ${ }^{\mathrm{TM}}$ Still Video system (EagleEye ${ }^{\mathrm{TM}}$, Stratagene, $\mathrm{UK})$ and arbitrary units assigned. Values are expressed as a ratio to $\beta$-actin.

\section{Immunohistochemistry}

Breast tissue was placed directly in the cryopreservative embedding media OCT compound (Tissue Tek, Sakura, Finetek, Europe BV, Zoeterwoude, The Netherlands) and immediately frozen in liquid nitrogen. Sections $(7 \mu \mathrm{m})$ were placed on glass slides coated with 2\% 3-amino-propyl-triethoxy-silane (Sigma-Aldrich Ireland Ltd, Dublin, Ireland) in acetone and dried for $12 \mathrm{~h}$ at room temperature. Tissue sections were fixed in $1 \%$ paraformaldehyde, air-dried and incubated for $15 \mathrm{~min}$ at room temperature with normal blocking serum (Vectastain Goat Elite Kit, Vector Laboratories Ltd, Peterborough, UK). The primary antibody for Ets-1 (C-20) was an IgG-purified rabbit polyclonal antibody raised against the peptide mapping at the carboxy-terminus of human Ets-1 $\left(200 \mu \mathrm{g} \mathrm{ml}^{-1}\right.$; Santa Cruz Biotechnology, Inc). The primary antibody was diluted $1: 100$ in $0.6 \mathrm{M} \mathrm{NaCl}$. Following $1 \mathrm{~h}$ incubation of the primary antibody at room temperature, a biotinylated rabbit secondary antibody $(1: 500)$ (Vector Laboratories, Burlingame, CA, USA) was applied to the sections, followed by the avidinbiotin-peroxidase complex ( $\mathrm{BBC}$ kit, Vectastain, Burlingame, CA, USA). Negative controls included preabsorption of the primary antibody with an excess of corresponding synthetic peptide (sc-350 p, $100 \mu \mathrm{g} 0.5^{-1} \mathrm{ml}$, Santa Cruz Biotechnology, Inc), and the use of isotype-matched nonimmune rabbit IgG.

\section{Immunofluorescent microscopy}

Immunofluorescent microscopy was carried out using the same procedure as that used for immunohistochemistry. Sections were incubated in diluted normal goat serum (Vector Laboratories, Burlingame, CA, USA). The primary polyclonal antibody for Ets-1
(C-20), as described previously, was diluted $1: 10$ in $10 \%$ normal human serum and incubated for $60 \mathrm{~min}$. Sections were washed in phosphate-buffered saline (PBS) and incubated for $30 \mathrm{~min}$ in biotinylated anti-rabbit secondary antibody (1:500, Vector Laboratories, Burlingame, CA, USA). Slides were washed thoroughly in PBS, and incubated in a 1:100 dilution of Cy3 fluorochrome-conjugated monoclonal mouse anti-biotin antibody (BN-34, Sigma Chemical Company, St Louis, MO, USA) for $30 \mathrm{~min}$. This was added to bind the biotinylated anti-rabbit secondary antibody. Following washing with PBS, the slides were mounted in Dako ${ }^{\mathbb{R}}$ fluorescent mounting medium (Dako Corporation, Carpinteria, CA, USA). Negative controls included the use of an isotype-matched nonimmune rabbit IgG and omission of the primary antibody.

\section{Enzyme-linked immunosorbent assay (ELISA)}

uPA ELISA kits were obtained from American Diagnostica Inc, Greenwich, CT, USA; oestrogen receptor (ER) and progesterone receptor (PR) ELISA kits were obtained from Abbott Diagnostics, North Chicago, IL, USA, and the HER-2/neu ELISA kits were obtained from Oncogene Research products, Cambridge, MA, USA. The supernatants prepared for Western blotting were used in the ELISA assays. All procedures were carried out using the manufacturers' recommended protocol. The cutoff values for ER and PR were 200 , and $1000 \mathrm{fmol} \mathrm{G}^{-1}$ wet weight tissue, respectively (Cullen et al, 2001).

\section{Statistical analysis}

The strength of associations between the various parameters measured in this study was tested using nonparametric tests, which do not assume that the data are normally distributed. Mann-Whitney $U$-tests were used for categorical data, and the Spearman rank correlation was used for continuous variables. Two-sided $P$-values below 0.05 were considered statistically significant.

\section{RESULTS}

\section{Expression of Ets-1 mRNA in fibroadenomas and primary breast carcinomas}

Representative expressions of Ets-1 and GAPDH mRNA detected by RT-PCR are shown in Figure 1A. GAPDH was used as an internal control and confirmed an equivalent amount of RNA loading for each sample used. Ets-1 mRNA was expressed in similar proportions of fibroadenomas ( 30 out of $42,71 \%$ ) and primary breast carcinomas (131 out of $179,73 \%)(P, N S)$. Although levels tended to be higher in the carcinomas compared to the fibroadenomas, this difference was not statistically significant (Figure 1A, B).

\section{Expression of Ets-1 protein in fibroadenomas and primary breast carcinomas}

Figure 2A shows Ets-1 protein expression measured by Western blotting. In total, four different proteins were detected: p51, which is regarded as full-length Ets-1, p52, which is thought to be a phosphorylated form of Ets-1 (Koizumi et al, 1990), p42, which is derived from a splice variant lacking exon VII (Bhat et al, 1996), and p33. The p33 form of Ets-1 does not appear to have been described previously in the literature. However, as this band was eliminated in the presence of excess blocking peptide (sc-350 p, $100 \mu \mathrm{g} 0.5^{-1} \mathrm{ml}$, Santa Cruz Biotechnology, Inc), (data not shown), it is likely to be a form of Ets-1 or at least Ets-1 related. Immunoreactivity of p42, p51 and p52 was also eliminated in the presence of excess blocking peptide (data not shown). 
A

MW Neg Pos Primary carcinomas Fibroadenomas
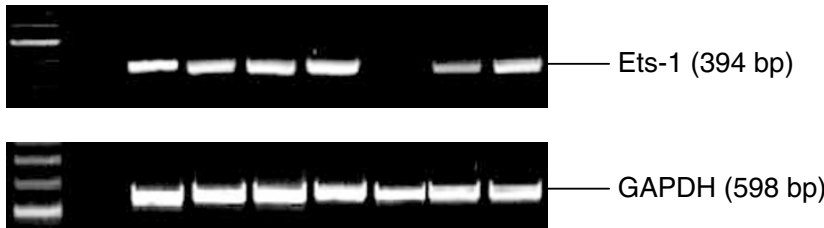

B

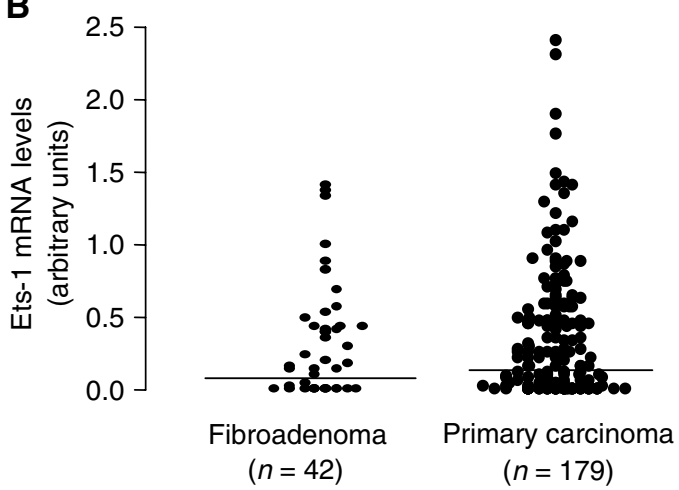

Figure I (A) Representative RT-PCR products of Ets-I and GAPDH detected in primary carcinomas and fibroadenomas; lane MW, 100 base pair DNA ladder; lane I, negative control without RT; lane 2, positive control for RT-PCR. (B) Distribution of Ets-I mRNA levels in fibroadenoma tissue and primary breast carcinomas as detected by RTPCR. Median levels are indicated by the bars. Each dot represents a semiquantitative value following scanning densitometry from one experiment. Values are expressed as a ratio to GAPDH.

Table 2 summarises the distribution of the four forms of the Ets-1 protein in fibroadenomas and primary breast carcinomas. For both carcinomas and fibroadenomas, the predominant form was p52, followed by p33 and p51. In the carcinomas, p42 was detected in only eight out of $78(10 \%)$ samples, while in the fibroadenomas this form was present in five out of $38(13 \%)$ samples. Levels of both p51 and p52, but not p33, were significantly higher in carcinomas compared to fibroadenomas (for p51, $P=0.007$; for p52, $P=0.02$; Mann - Whitney $U$-test).

Typical immunostaining patterns for Ets-1 in primary breast carcinoma tissue and fibroadenoma tissue sections are shown in Figure 3. Haematoxylin and eosin-stained sections were used to select the most cellular part of the tissue sections and the area with the lowest architectural differentiation. We found strong Ets-1 staining in the primary breast carcinoma tissue sections (Figure 3A,B), especially on the tumour cells (Figure 3B). Some stromal cell staining was also observed, especially surrounding the tumour islands. Most of the Ets-1 staining was found to be nuclear, although some cytoplasmic staining was also seen. In the fibroadenomas, epithelial and stromal cell staining was also observed (Figure 3 ). The specificity of Ets-1 antibody staining was confirmed by an absence of reactivity on serial sections treated with Ets-1 antibody that had been preincubated with an excess of specific antigen (result not shown). Immunostaining with isotype-matched nonimmune rabbit IgG yielded a complete absence of staining in all sections stained (result not shown). Immunofluorescent microscopy was also carried out on the primary breast carcinoma sections $(n=7)$. Both nuclear and cytoplasmic localisations of Ets-1 were observed (Figure 3C).
A
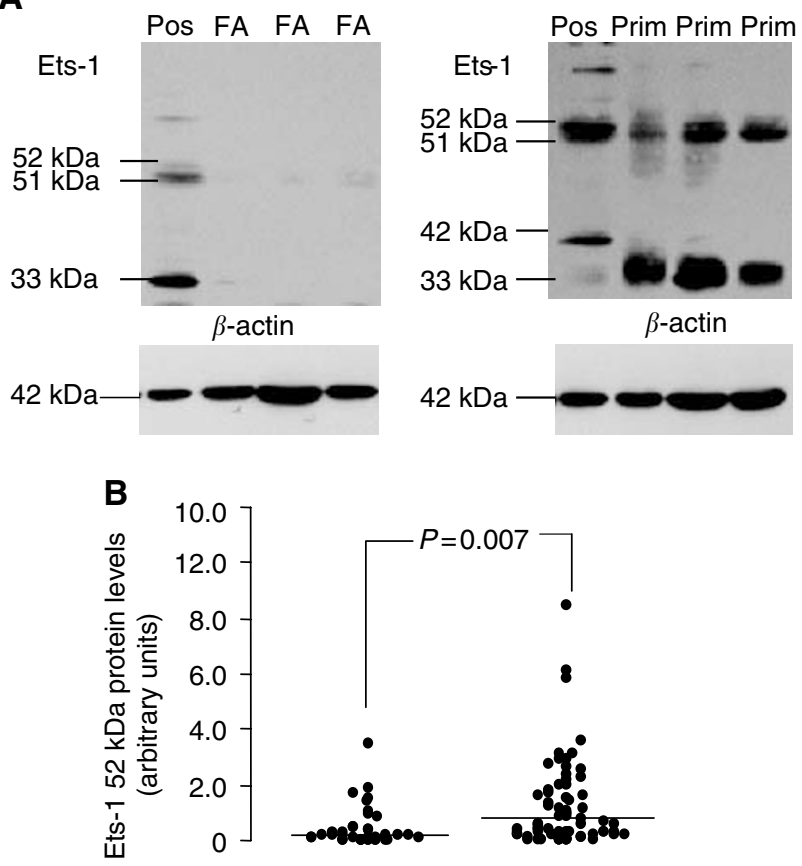

Fibroadenoma Primary carcinoma $(n=38)$ $(n=78)$
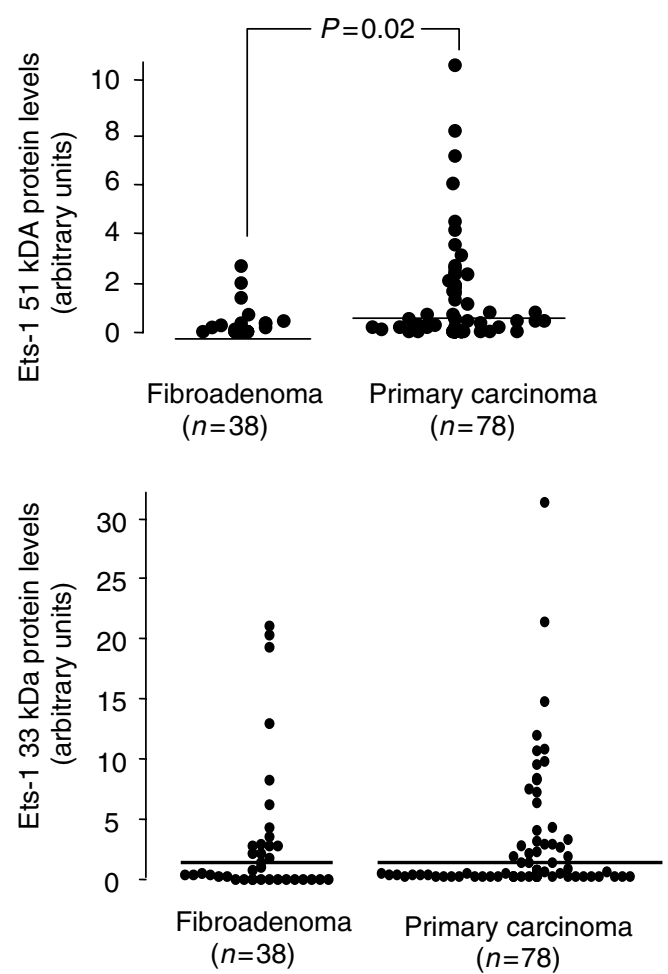

Figure 2 (A) Ets-I protein expression in primary carcinomas and fibroadenomas. Levels of Ets-I protein were determined by Western blotting as described under 'Materials and methods'. FA denotes fibroadenoma tissue, Prim. denotes primary breast carcinomas and Pos. denotes positive control (Jurkat cell lysate). Arrows show Ets-I p5 I, p52, p33 and p42 proteins detected using an Ets-I-specific antibody. (B) Distribution of Ets-I p52, p5 I and p33 levels in primary carcinomas and fibroadenomas as detected by Western blotting. Median levels are indicated by the bars. Each dot represents a semiquantitative value following scanning densitometry from one experiment. Values are expressed as a ratio to $\beta$-actin. 


\section{Relationship between Ets-1 protein and uPA}

Since uPA is causally involved in tumour progression (Duffy et al, 1988), we correlated its levels with those of Ets-1. As shown in Figure 4, a statistically significant relationship was found to exist between $\mathrm{uPA}$ and the 52,51 and $33 \mathrm{kDa}$ forms of the Ets- 1 protein in the primary carcinomas (for p51, $r=0.38, P=0.01$; for $\mathrm{p} 52$, $r=0.40, P=0.01$; for $\mathrm{p} 33, r=0.48, P=0.002$; Spearman rank nonparametric test) (Figure $4 \mathrm{~A}-\mathrm{C}$ ).

\section{Relationship between Ets-1 and established prognostic factors in breast cancer}

Neither Ets-1 mRNA nor any form of the Ets-1 protein correlated significantly with tumour size, nodal status, histology type ER or PR levels (Table 3). Although there were relatively few matched values for Ets-1 protein and HER-2/neu $(n=35)$, a significant relationship was observed between the phosphorylated form of the Ets-1 protein $(52 \mathrm{kDa})$ and HER-2/neu levels $(r=0.43, P=0.01$; Spearman rank nonparametric test) (Figure 5). No significant relationship however was found between p51, p33, p42 and HER-2/ neu levels.

Table 2 Distribution of the main forms of the Ets-I protein in fibroadenomas and primary breast carcinomas

Fibroadenoma $(n=38) \quad$ Primary breast carcinoma $(n=78)$

\begin{tabular}{|c|c|c|c|c|c|c|}
\hline \multicolumn{4}{|c|}{ No. pos. \% pos Median level } & \multirow{2}{*}{$\frac{\text { No. pos. }}{52}$} & \multirow{2}{*}{$\frac{\% \text { pos }}{67}$} & \multirow{2}{*}{$\begin{array}{c}\text { Median level } \\
0.36\end{array}$} \\
\hline p33 & 27 & 74 & 0.44 & & & \\
\hline $\mathrm{p} 42$ & 5 & 13 & 0 & 8 & 10 & 0 \\
\hline p5l & 18 & 47 & 0 & 44 & 56 & 0.19 \\
\hline p52 & 32 & 84 & 0.18 & 65 & 83 & 0.44 \\
\hline
\end{tabular}

Figure 3 (A) Ets-I staining of frozen sections of fibroadenoma. Immunohistochemical staining of fibroadenoma tissue showing Ets-I protein distributution mainly around the lobules and ducts and also in the stromal fibroblasts. Some negatively stained cells are also seen in the surrounding stromal tissue. Immunoperoxidase staining of sections was carried out using the Vectastain Elite $A B C$ kit (Vector Laboratories) on $7 \mu \mathrm{m}$ sections of frozen breast tissue embedded in OCT according to the manufacturer's recommendations. (A) Fibroadenoma tissue section $\times 20$ (objective); (B) rabbit IgG-negative control $\times 20$ (objective); (C) $\times 40$ showing Ets-I staining in the epithelial cells lining the ducts and also in the surrounding stroma; (D) IgG control $\times 40$. (B) Ets-I staining of frozen sections of breast tumour tissue. Immunohistochemical staining of breast tumour tissue showing Ets-I protein distributution mainly in the tumour cells and to a lesser extent in the stromal fibroblasts surrounding the tumour islands. Some negatively stained cells are also seen in the surrounding stromal tissue. Immunoperoxidase staining of sections was carried out using the Vectastain Elite $A B C$ kit (Vector Laboratories) on $7 \mu \mathrm{m}$ sections of frozen breast tissue embedded in OCT according to the manufacturer's recommendations. (A) Breast tumour tissue section $\times 20$ (objective); (B) rabbit IgG negative control $\times 20$ (objective); $(C) \times 40$ showing Ets-I staining in the tumour cells; (D) IgG control $\times 40$; $(E) \times 60$ showing a cluster of tumour cells stained positively for Ets- I; (F) IgG control $\times 60$. (C) Localisation of Ets-I protein in breast tumour tissue by immunofluorescent microscopy. Ets-I staining is observed in both the nucleus and cytoplasm of the tumour cells in the primary breast cancer tissue sections. (A) Arrow shows Ets-I cytoplasmic staining (original magnification $\times 200)$; $($ B) arrow shows Ets-I nuclear staining.

\section{DISCUSSION}

Ets proteins regulate the expression of multiple genes involved in cancer dissemination and have been associated with invasiveness in model systems (Sementchenko and Watson, 2000). Despite this, a distinct biological role for the Ets proteins in human cancer has yet to be established. In this investigation, Ets-1 mRNA was found

A
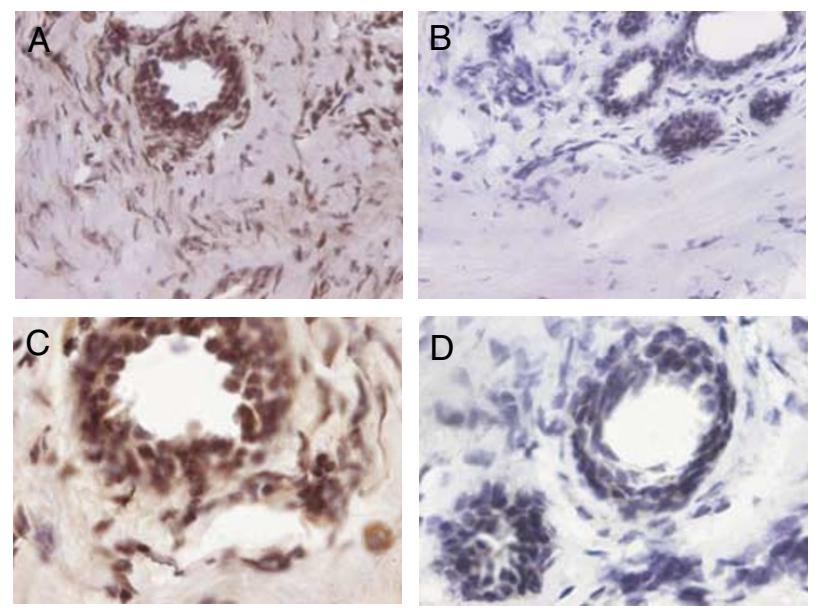

B
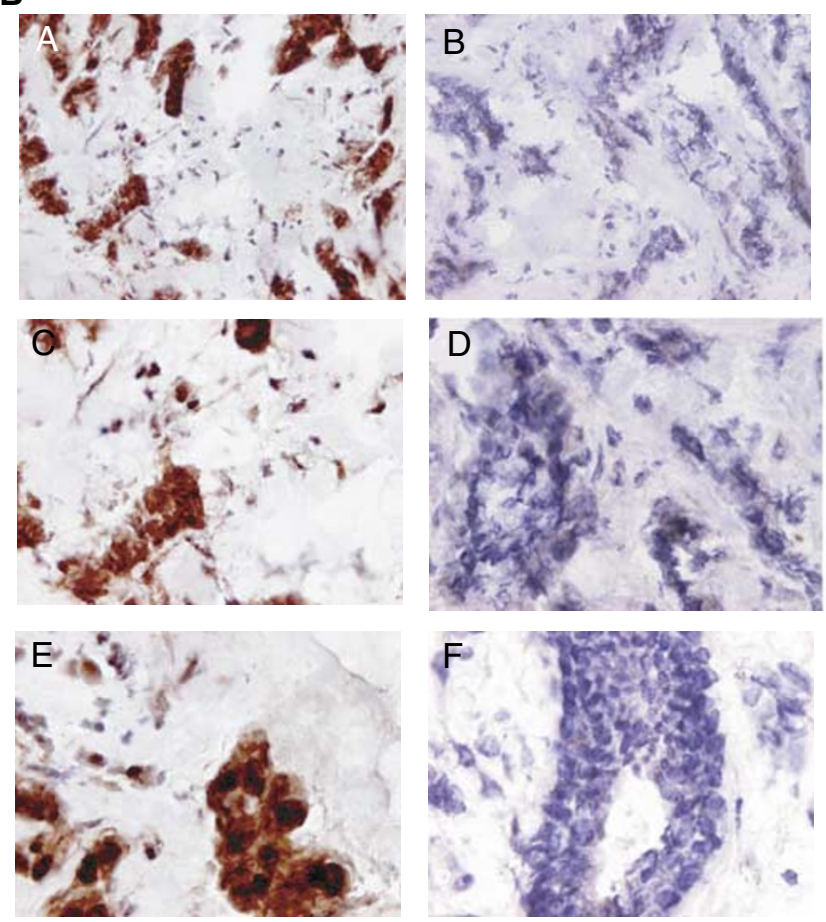

C
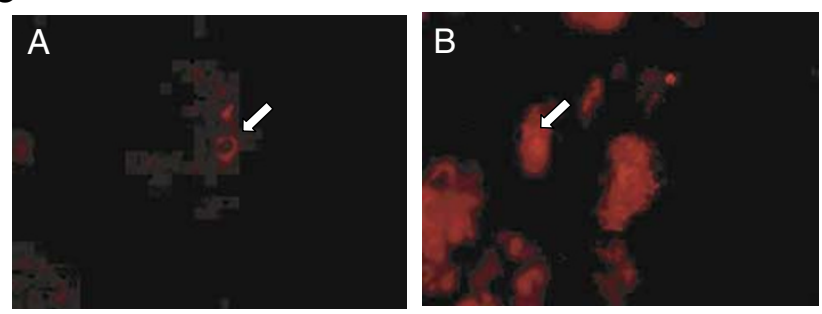

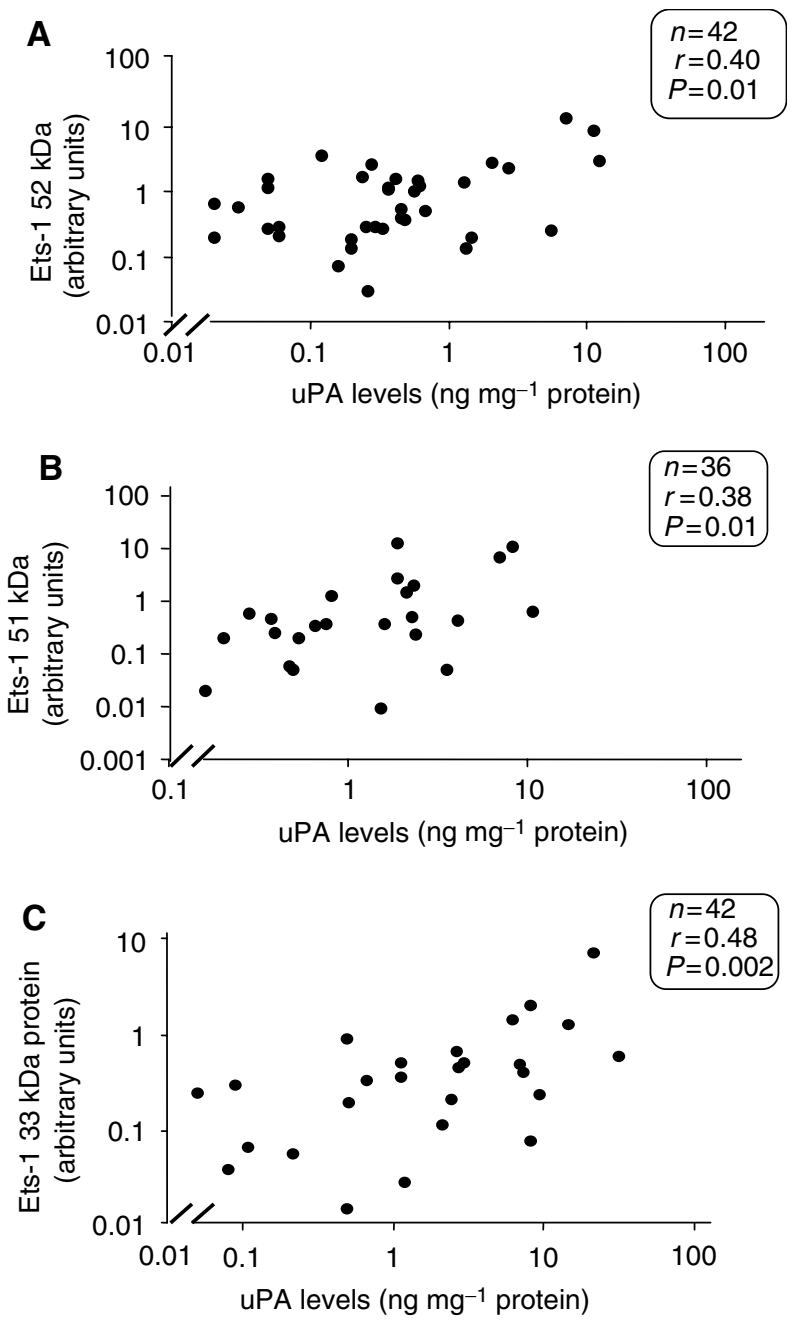

Figure 4 Relationship between Ets-I $52 \mathrm{kDa}$ and $\mathrm{uPA}$ protein $(\mathbf{A})$ and Ets-I 5 I kDa protein and uPA (B) and Ets- I $33 \mathrm{kDa}$ and uPA (C). Ets- I protein measurements were carried out using Western blotting. Arbitrary units were assigned to each protein band following scanning densitometry. Values are expressed as a ratio to $\beta$-actin. uPA protein was measured using ELISA. Data was analysed using the nonparametric Spearman rank test.

to be expressed at similar levels in breast carcinomas and fibroadenomas. In contrast to findings at the mRNA level, concentrations of the two main protein forms of Ets-1, that is, p51 and p52, were significantly increased in carcinomas compared to the fibroadenomas. The increase in expression of Ets-1 protein compared to Ets-1 mRNA in the primary carcinomas may relate to enhanced translation in the malignant $v s$ the benign tissues. Previously, using in situ hybridisation, mRNA for Ets-1 was reported to be increased in invasive breast cancers vis-à-vis in in situ lesions (Behrens et al, 2001). To our knowledge, no previous report has compared Ets-1 expression in fibroadenomas and carcinomas.

In addition to p51 and p52, two further forms of the Ets-1 protein, that is, $\mathrm{p} 42$ and $\mathrm{p} 33$, were detected in the present investigation. $\mathrm{p} 42$ is derived from an mRNA splice variant lacking exon VII and has previously been detected in both benign and malignant breast tumours (Behrens et al, 2001). In MDA-MB-231 breast cancer cells but not MCF-7 cells, overexpression of the p42 form of Ets-1 was found to reduce cell survival (Ballschmieter et al, 2003). On the other hand, in colon cancer cells, the $\mathrm{p} 42$ form of the

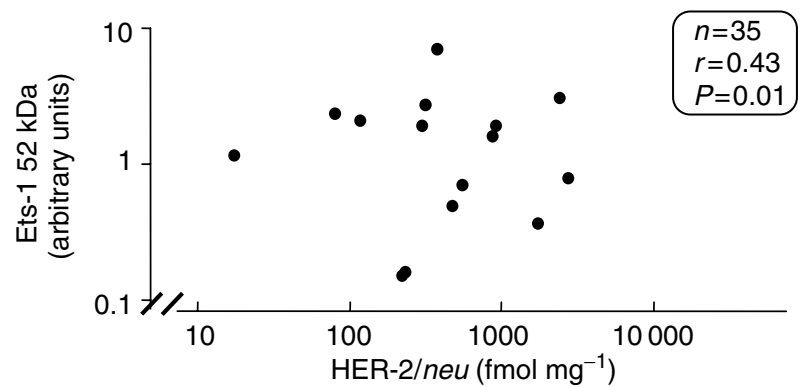

Figure 5 Relationship between Ets-I $52 \mathrm{kDa}$ protein and HER-2/neu $\left(\mathrm{fmol} \mathrm{mg} \mathrm{g}^{-1}\right.$ ). Ets-I protein measurements were carried out using Western blotting. Arbitrary units were assigned to each protein band following scanning densitometry. Values are expressed as a ratio to $\beta$-actin. HER-2/ neu levels were measured using ELISA. Data was analysed using the nonparametric Spearman rank test.

Ets-1 protein was shown to rescue Fas-induced apoptosis (Li et al, 1999). The $\mathrm{p} 33$ protein band reported here does not appear to have been described previously, and its identity remains unknown. A p39 form of Ets-1 previously reported by Koizumi et al (1990) was not detected in this study. This form of the Ets-1 protein is thought to be derived from the p51 protein by covalent modification of the protein by a synthetic protease inhibitor and thus may be a product of the specific extraction method (Fisher et al, 1992).

In this investigation, we found the Ets-1 protein to be present in both tumour and stromal cells, especially when the latter surrounded tumour islands. Using both immunohistochemistry and in situ hybridisation, Behrens et al (2001) detected expression of Ets-1 in stromal fibroblasts, endothelial cells and epithelial cells in breast cancers. In the endothelial cells, upregulation occurred during the onset of angiogenesis around the in situ carcinoma. In ovarian (Davidson et al, 2001) and lung carcinomas (Bolon et al, 1995), expression of Ets-1 has also been observed in both stromal and tumour cells. In oral squamous cell cancers, Ets-1 was found in endothelial cells of well-vascularised tumours (Pande et al, 1999).

In the present study, no significant correlation was found between Ets-1 expression and either tumour size, nodal status, ER or PR status. In colorectal cancer, however, expression of Ets-1 protein was found to be significantly associated with lymph node status, depth of invasion and lymphatic invasion (Nakayama et al, 2001). Also, in lung cancer, Ets-1 protein levels correlated with tumour size, lymph node status and tumour stage (Bolon et al, 1995).

Although no significant relationship was found between Ets-1 expression and established prognostic factors in this study, the p33, p51 and p52 forms of the Ets-1 protein correlated significantly with uPA levels. UPA is a serine protease causally involved in invasion and metastasis, and is one of the most potent biological prognostic factors so far described in breast cancer (Duffy et al, 1998). Recently, its prognostic value was also validated for nodenegative breast cancer patients using two different level 1 evidence studies, that is, in both a randomised prospective trial (Foekens et $a l, 2000$ ) and a pooled analysis (Look et al, 2002). Consistent with our studies showing a significant relationship between Ets-1 and uPA, Span et al (2002) recently reported an association between Ets-1 and poor prognosis in breast cancer. In contrast to our results, Span et al (2002) found no significant correlation between Ets-1 and uPA in breast cancer. A significant relationship, however, was found between Ets-1 and PAI-1, an inhibitor of uPA (Span et al, 2002). The significant correlation between Ets-1 proteins, that is, p52, p51, p33 and uPA, in this study is consistent with previous reports showing the presence of EBSs in the enhancer/promoter elements of the $u P A$ gene (Watabe et al, 1998; Sementchenko and Watson, 2000). Indeed, evidence from multiple 
Table 3 Ets-I mRNA and protein expression in different subsets of primary breast carcinomas

\begin{tabular}{|c|c|c|c|c|c|c|c|c|c|c|}
\hline & \multicolumn{2}{|c|}{ Ets-I mRNA } & \multicolumn{2}{|c|}{ Ets-I p52 } & \multicolumn{2}{|c|}{ Ets-I p5 I } & \multicolumn{2}{|c|}{ Ets-I p42 } & \multicolumn{2}{|c|}{ Ets-I p33 } \\
\hline & $n$ & No. Pos (\%) & $n$ & No. Pos. (\%) & $n$ & No. Pos. (\%) & $n$ & No. Pos. (\%) & $n$ & No. Pos. (\%) \\
\hline \multicolumn{11}{|l|}{ Nodal status } \\
\hline Negative & 80 & $62(78)$ & 32 & $27(84)$ & 32 & $18(56)$ & 32 & $6(19)$ & 32 & $22(69)$ \\
\hline Positive & 89 & $63(71)$ & 39 & $33(85)$ & 39 & $22(56)$ & 39 & I (2.5) & 39 & $26(67)$ \\
\hline Unknown & 10 & & 7 & & 7 & & 7 & & 7 & \\
\hline \multicolumn{11}{|l|}{ Tumour size } \\
\hline $\mathrm{TI}(\leqslant 2 \mathrm{~cm})$ & 45 & $34(76)$ & 17 & $15(88)$ & 17 & $14(82)$ & 17 & I (6) & 17 & $15(88)$ \\
\hline $\mathrm{T} 2(2-5 \mathrm{~cm})$ & 91 & $68(75)$ & 38 & $30(79)$ & 38 & $16(42)$ & 38 & $4(1 \mid)$ & 38 & $21(55)$ \\
\hline $\mathrm{T} 3-4(\geqslant 5 \mathrm{~cm})$ & 29 & $18(62)$ & 18 & $15(83)$ & 18 & $10(56)$ & 18 & I (6) & 18 & II (6I) \\
\hline Unknown & 14 & & 5 & & 5 & & 5 & & 5 & \\
\hline \multicolumn{11}{|l|}{ Histology type } \\
\hline Ductal (D) & 133 & $98(70)$ & 61 & $53(87)$ & 61 & $3 \mid(5 \mid)$ & 61 & $6(9.8)$ & 61 & $40(66)$ \\
\hline Lobular (L) & 27 & $20(74)$ & 7 & $6(86)$ & 7 & $6(86)$ & 7 & I (14) & 7 & $5(7 \mid)$ \\
\hline$D \& L$ & 10 & 7 (70) & 6 & $2(33)$ & 6 & $4(67)$ & 6 & $0(0)$ & 6 & $4(44)$ \\
\hline Unknown & 9 & & 4 & & 4 & & 4 & & 4 & \\
\hline \multicolumn{11}{|l|}{ ER status ${ }^{\mathrm{a}}$} \\
\hline Negative & 50 & $37(74)$ & 20 & $15(75)$ & 20 & $10(50)$ & 20 & I (5) & 20 & $13(65)$ \\
\hline Positive & 128 & 93 (73) & 56 & $49(88)$ & 56 & 33 (59) & 56 & $6(11)$ & 56 & 37 (66) \\
\hline Unknown & 1 & & 2 & & 2 & & 2 & & 2 & \\
\hline \multicolumn{11}{|l|}{ PR status ${ }^{\mathrm{b}}$} \\
\hline Negative & 73 & $53(73)$ & 36 & $30(83)$ & 36 & $16(44)$ & 36 & $3(8)$ & 36 & $26(72)$ \\
\hline Positive & 77 & 93 (73) & 35 & $30(86)$ & 35 & $23(66)$ & 35 & $3(9)$ & 35 & $20(57)$ \\
\hline Unknown & 29 & & 7 & & 7 & & 7 & & 7 & \\
\hline
\end{tabular}

$\mathrm{ER}=$ oestrogen receptor. $\mathrm{PR}=$ progesterone receptor. ${ }^{\mathrm{a} C u t o f f}$ point $=200 \mathrm{fmol} \mathrm{g}{ }^{-1}$ of wet weight tissue. ${ }^{\mathrm{b}} \mathrm{Cutoff}$ point $=1000 \mathrm{fmol} \mathrm{g}^{-1}$ of wet weight tissue.

model systems suggest that the Ets-1 transcription factor may be one of the important regulators controlling the involvement of uPA in the invasive process (Watabe et al, 1998; Nakada et al, 1999; Sementchenko and Watson, 2000).

In addition to correlating with $\mathrm{UPA}$, we also found a significant relationship between the p52 form of Ets-1 and HER-2/neu. HER$2 /$ neu is a proto-oncogene overexpressed in $15-30 \%$ of invasive breast cancers (Slamon et al, 1989). In model systems, overexpression has been associated with both tumorigenesis and metastasis (Slamon and Clark, 1988). In human breast cancers, increased levels are generally associated with adverse outcome (Allred et al, 1992). Previously, another member of the Ets family, that is, PEA3, was also found to correlate with HER-2/neu in breast cancer (Shepherd et al, 2001) and EBSs have been found in the HER-2/neu promoter (Chiang et al, 2000). Our finding of a correlation between Ets-1 protein levels and both HER-2/neu and uPA is consistent with previous data showing a role for Ets-1 in invasive processes (Vandenbunder et al, 1994a; Wernert et al, 1994; Nakada et al, 1999; Pande et al, 1999; Kitange et al, 2000; Naito et al, 2000).

In conclusion, this is one of the most detailed reports to date on an Ets protein in a human cancer. Our results show that certain forms of the Ets-1 protein, that is, p52 and p51, are expressed at much higher levels in breast cancer compared to fibroadenomas. Since multiple signalling pathways converge on Ets transcription factors (Wasylyk et al, 1998), the latter should be logical targets for new anticancer agents. Finally, since Ets-1 proteins correlate with both uPA and HER-2/neu, high levels are likely to be associated with aggressive disease.

\section{REFERENCES}

Allred DC, Clark GM, Molina R, Tandon AK, Schnitt SJ, Gilchrist KW, Osborne CK, Tormey DC, McGuire WL (1992) Overexpression of HER-2/ neu and its relationship with other prognostic factors change during the progression of in situ to invasive breast cancer. Hum Pathol 23: 974-979

Ballschmieter P, Braig M, Lindemann RK, Nordheim A, Dittmer J (2003) Splicing variant DeltaVII-Ets1 is downregulated in invasive Ets1expressing breast cancer cells. Int J Oncol 22: 849-853

Behrens P, Rothe M, Wellmann A, Krischler J, Wernert N (2001) The Ets-1 transcription factor is up-regulated together with MMP 1 and MMP 9 in the stroma of pre-invasive breast cancer. J Pathol 194: 43-50

Bhat NK, Fischinger PJ, Seth A, Watson DK, Papas T (1996) Pleiotropic functions of ETS-1 (review). Int J Oncol 8: 841-846

Bolon I, Gouyer V, Devouassoux M, Vandenbunder B, Wernert N, Moro D, Brambilla C, Brambilla E (1995) Expression of c-ets-1, collagenase 1, and urokinase-type plasminogen activator genes in lung carcinomas. $\mathrm{Am} \mathrm{J}$ Pathol 147: $1298-1310$
Chiang SY, Burli RW, Benz CC, Gawron L, Scott GK, Dervan PB, Beerman TA (2000) Targeting the ets binding site of the HER2/neu promoter with pyrrole-imidazole polyamides. J Biol Chem 275: $24246-24254$

Chomczynski P, Sacchi N (1987) Single-step method of RNA isolation by acid guanidinium thiocyanate-phenol-chloroform extraction. Anal Biochem 162: 156-159

Collyn d'Hooghe M, Galiegue-Zouitina S, Szymiczek D, Lantoine D, Quief S, Loucheux-Lefebvre MH, Kerckaert JP (1993) Quantitative and qualitative variation of ETS-1 transcripts in hematologic malignancies. Leukemia 7: $1777-1785$

Crofford LJ, Sano H, Karalis K, Friedman TC, Epps HR, Remmers EF, Mathern P, Chrousos GP, Wilder RL (1993) Corticotropin-releasing hormone in synovial fluids and tissues of patients with rheumatoid arthritis and osteoarthritis. J Immunol 151: $1587-1596$ 
Cullen R, Maguire TM, McDermott EW, Hill AD, O'Higgins NJ, Duffy MJ (2001) Studies on oestrogen receptor-alpha and -beta mRNA in breast cancer. Eur J Cancer 37: 1118-1122

Davidson B, Reich R, Goldberg I, Gotlieb WH, Kopolovic J, Berner A, BenBaruch G, Bryne M, Nesland JM (2001) Ets-1 messenger RNA expression is a novel marker of poor survival in ovarian carcinoma. Clin Cancer Res 7: $551-557$

Duffy MJ, Duggan C, Mulcahy HE, McDermott EW, O’Higgins NJ (1998) Urokinase plasminogen activator: a prognostic marker in breast cancer including patients with axillary node-negative disease. Clin Chem 44: $1177-1183$

Duffy MJ, O'Grady P, Devaney D, O'Siorain L, Fennelly JJ, Lijnen HJ (1988) Urokinase-plasminogen activator, a marker for aggressive breast carcinomas. Preliminary report. Cancer 62: $531-533$

Fisher RJ, Koizumi S, Kondoh A, Mariano JM, Mavrothalassitis G, Bhat NK, Papas TS (1992) Human ETS1 oncoprotein. Purification, isoforms, -SH modification, and DNA sequence-specific binding. $J$ Biol Chem 267: $17957-17965$

Foekens JA, Peters HA, Look MP, Portengen H, Schmitt M, Kramer MD, Brunner N, Janicke F, Meijer-van Gelder ME, Henzen-Logmans SC, van Putten WL, Klijn JG (2000) The urokinase system of plasminogen activation and prognosis in 2780 breast cancer patients. Cancer Res 60: $636-643$

Higashino F, Yoshida K, Noumi T, Seiki M, Fujinaga K (1995) Ets-related protein E1A-F can activate three different matrix metalloproteinase gene promoters. Oncogene 10: $1461-1463$

Himelstein BP, Lee EJ, Sato H, Seiki M, Muschel RJ (1997) Transcriptional activation of the matrix metalloproteinase-9 gene in an H-ras and v-myc transformed rat embryo cell line. Oncogene 14: 1995-1998

Ito M, Nakayama T, Naito S, Matsuu M, Shichijo K, Sekine I (1998) Expression of Ets-1 transcription factor in relation to angiogenesis in the healing process of gastric ulcer. Biochem Biophys Res Commun 246: $123-127$

Janknecht R, Nordheim A (1993) Gene regulation by Ets proteins. Biochim Biophys Acta 1155: 346-356

Jorcyk CL, Watson DK, Mavrothalassitis GJ, Papas TS (1991) The human ETS1 gene: genomic structure, promoter characterization and alternative splicing. Oncogene 6: 523-532

Kitange G, Shibata S, Tokunaga Y, Yagi N, Yasunaga A, Kishikawa M, Naito S (1999) Ets-1 transcription factor-mediated urokinase-type plasminogen activator expression and invasion in glioma cells stimulated by serum and basic fibroblast growth factors. Lab Invest 79: 407-416

Kitange G, Tsunoda K, Anda T, Nakamura S, Yasunaga A, Naito S, Shibata S (2000) Immunohistochemical expression of Ets-1 transcription factor and the urokinase-type plasminogen activator is correlated with the malignant and invasive potential in meningiomas. Cancer 89: $2292-2300$

Koizumi S, Fisher RJ, Fujiwara S, Jorcyk C, Bhat NK, Seth A, Papas TS (1990) Isoforms of the human ets-1 protein: generation by alternative splicing and differential phosphorylation. Oncogene 5: 675-681

Li R, Pei H, Papas T (1999) The p42 variant of ETS1 protein rescues defective Fas-induced apoptosis in colon carcinoma cells. Proc Natl Acad Sci USA 96: $3876-3881$

Look MP, van Putten WL, Duffy MJ, Harbeck N, Christensen IJ, Thomssen C, Kates R, Spyratos F, Ferno M, Eppenberger-Castori S, Sweep CG, Ulm K, Peyrat JP, Martin PM, Magdelenat H, Brunner N, Duggan C, Lisboa BW, Bendahl PO, Quillien V, Daver A, Ricolleau G, Meijer-Van Gelder ME, Manders P, Fiets WE, Blankenstein MA, Broet P, Romain S, Daxenbichler G, Windbichler G, Cufer T, Borstnar S, Kueng W, Beex LV, Klijn JG, O'Higgins N, Eppenberger U, Janicke F, Schmitt M, Foekens JA (2002) Pooled analysis of prognostic impact of urokinase-type plasminogen activator and its inhibitor PAI-1 in 8377 breast cancer patients. J Natl Cancer Inst 94: 116-128

Mavrothalassitis G, Fisher RJ, Smyth F, Watson DK, Papas TS (1994) Structural inferences of the ETS1 DNA-binding domain determined by mutational analysis. Oncogene 9: 425-435
Naito S, Shimizu K, Nakashima M, Nakayama T, Ito T, Ito M, Yamashita S, Sekine I (2000) Overexpression of Ets-1 transcription factor in angiosarcoma of the skin. Pathol Res Pract 196: 103-109

Nakada M, Yamashita J, Okada Y, Sato H (1999) Ets-1 positively regulates expression of urokinase-type plasminogen activator (uPA) and invasiveness of astrocytic tumors. J Neuropathol Exp Neurol 58: 329-334

Nakayama T, Ito M, Ohtsuru A, Naito S, Sekine I (2001) Expression of the ets-1 proto-oncogene in human colorectal carcinoma. Mod Pathol 14: $415-422$

Pande P, Mathur M, Shukla NK, Ralhan R (1999) Ets-1: a plausible marker of invasive potential and lymph node metastasis in human oral squamous cell carcinomas. $J$ Pathol 189: $40-45$

Papas TS, Fisher RJ, Bhat N, Fujiwara S, Watson DK, Lautenberger J, Seth A, Chen ZQ, Burdett L, Pribyl L, Schweinfest CW, Ascione R (1989) The ets family of genes: molecular biology and functional implications. Curr Top Microbiol Immunol 149: $143-147$

Pognonec P, Boulukos KE, Bosselut R, Boyer C, Schmitt-Verhulst AM, Ghysdael J (1990) Identification of a Ets1 variant protein unaffected in its chromatin and in vitro DNA binding capacities by $\mathrm{T}$ cell antigen receptor triggering and intracellular calcium rises. Oncogene 5: 603-610

Sato Y, Abe M, Tanaka K, Iwasaka C, Oda N, Kanno S, Oikawa M, Nakano T, Igarashi T (2000) Signal transduction and transcriptional regulation of angiogenesis. Adv Exp Med Biol 476: 109-115

Sementchenko VI, Watson DK (2000) Ets target genes: past, present and future. Oncogene 19: 6533-6548

Shepherd TG, Kockeritz L, Szrajber MR, Muller WJ, Hassell JA (2001) The pea3 subfamily ets genes are required for HER2/Neu-mediated mammary oncogenesis. Curr Biol 11: 1739-1748

Slamon DJ, Clark GM (1988) Amplification of c-erbB-2 and aggressive human breast tumors? Science 240: $1795-1798$

Slamon DJ, Godolphin W, Jones LA, Holt JA, Wong SG, Keith DE, Levin WJ, Stuart SG, Udove J, Ullrich A, McGuire WL (1989) Studies of the HER-2/neu proto-oncogene in human breast and ovarian cancer. Science 244: $707-712$

Span PN, Manders P, Heuvel JJ, Thomas CM, Bosch RR, Beex LV, Sweep CG (2002) Expression of the transcription factor Ets-1 is an independent prognostic marker for relapse-free survival in breast cancer. Oncogene 21: $8506-8509$

Tymms MJ, Kola I (1994) Regulation of gene expression by transcription factors Ets-1 and Ets-2. Mol Reprod Dev 39: 208-214

Vandenbunder B, Queva C, Desbiens X, Wernert N, Stehelin D (1994a) Expression of the transcription factor c-Ets1 correlates with the occurrence of invasive processes during normal and pathological development. Invas Metastasis 14: $198-209$

Vandenbunder B, Wernert N, Queva C, Desbiens X, Stehelin D (1994b) Does the transcription factor c-ets1 take part in the regulation of angiogenesis and tumor invasion? Folia Biol 40: $301-313$

Wasylyk B, Hagman J, Gutierrez-Hartmann A (1998) Ets transcription factors: nuclear effectors of the Ras-MAP-kinase signaling pathway. Trends Biochem Sci 23: 213-216

Wasylyk B, Hahn SL, Giovane A (1993) The Ets family of transcription factors. Eur J Biochem 211: 7-18

Watabe T, Yoshida K, Shindoh M, Kaya M, Fujikawa K, Sato H, Seiki M, Ishii S, Fujinaga K (1998) The Ets-1 and Ets-2 transcription factors activate the promoters for invasion-associated urokinase and collagenase genes in response to epidermal growth factor. Int J Cancer 77: 128-137

Watson DK, Ascione R, Papas TS (1990) Molecular analysis of the ets genes and their products. Crit Rev Oncog 1: 409-436

Wernert N, Gilles F, Fafeur V, Bouali F, Raes MB, Pyke C, Dupressoir T, Seitz G, Vandenbunder B, Stehelin D (1994) Stromal expression of c-Ets1 transcription factor correlates with tumor invasion. Cancer Res 54: $5683-5688$

White LA, Maute C, Brinckerhoff CE (1997) ETS sites in the promoters of the matrix metalloproteinases collagenase (MMP-1) and stromelysin (MMP-3) are auxiliary elements that regulate basal and phorbol-induced transcription. Connect Tissue Res 36: 321-335 